\title{
An Analysis of the Characters in A Streetcar Named Desire
}

\author{
Yang Zhao \\ Foreign Languages College, Beihua University, Jilin 132013, China.
}

Keywords: Tennessee Williams analysis of characters conflict

\begin{abstract}
A Streetcar Named Desire puts forward with an incisive opinion about institutions as well as the manner of postwar America imposed restrictions on women's lives, and also describes the embarrassing situation of Southern women in society. This thesis collects much relevant information about the writer and the information of this play. Furthermore, relatively deep research about the character of the main person is made here; the reasons of the character developing include the influence of writer's experiences and the influence of the whole society at that time. Due to the diversity of people's characters, apparent conflicts and potential conflicts appear in the play and add to the glory. Here the main conflicts would also be analyzed.
\end{abstract}

\section{Introduction}

A Streetcar Named Desire was one of Williams' most famous and most popular plays, which won the Pulitzer Prize for Drama, the Donaldson Awards and the New York Drama Critics' Circle Awards, the first one ever to win all three. His drama A Streetcar Named Desire was always on the short list of the finest American plays in the $20^{\text {th }}$ century alongside Long Days Journey into Night and Death of a Salesman. In the year of 1947, the play of A Streetcar Named Desire came into being, the first show in Broadway of New York let countless spectators being crazy about it. Then act 561 times altogether in all kinds of theaters. It's an unprecedented success at that time. In 1951, the play was developed into a movie. And the movie was one of the most important movies in the world. In 1952, the movie won 12 awards in Oscar. A Streetcar Named Desire related to many topics such as: the north and the south, sex, homosexual and so on. These have attracted much more attention than other plays ever before. However, these also brought a lot of critics.

A Streetcar Named Desire was a story about the process in which lazy Blanch from the south went crazy. Blanche took the bus named Desire to go and seek refuge with her sister — Stella. She had experienced unbearable suffering and expected to have a happy life with her sister. However, it's the start point of her miserable ending. She was an English teacher and fired because of seducing the schoolboy. After Blanch met her sister, her sister's husband Stanley hated her feigned aristocratic style and had a strained relationship with Blanche. But a tender man named Mitch was completely smitten with her charm. Blanche was so happy to find a man who wanted to marry her. Good time didn't last long. Stanley knew her past; he was shocked so that he told Mitch and Stella. Blanch lost the only hope of new life. She was despaired but she still tried to keep good manner and pretend she was fine. Her endless falsehood annoyed Stanley badly. He insulted her by most seriously way - he raped her when Stella gave birth to a baby in hospital. Poor Blanch got mad eventually and was taken away by people from mental hospital.

\section{Blanche}

Blanche Dubois was the heroine in the play. The traditional drama adopt dichotomy to write female character, either vestal virgin or dissolute woman. But Williams gave this role multiplicity and contradiction. Choosing "Blanche Dubois" to be the heroine's name reflected the tragedy disruptive of her character. "Blanche Dubois" meant "white forest" in French. While "white" meant pure, noble and fragile, “forest” presented Blanche's inner mysterious world which weaved by death and desire. The complexity and contradiction of her character led to the inevitability of her tragic fate. Let’s begin from Blanche’s legendary experience. The Blanche represented the myth of 
the old south. Blanche was an ambiguous feminine. Born into an old Southern family and raised at Belle Reve (a traditional south plantation), Blanche had been educated to accept the traditional Southern moral codes and way of life. The character of duality was her unique charm in the American play.

There were three conflicts in her character, the first one was dignity and hypocrisy. On one hand, she was a refined, cultured beautiful lady who maintained traditional merits of South belle. On the other hand, she was a lonely, miserable, old maid who had experienced a great deal of sufferings. The second one was purity and carnality, Blanche ought to be a pure girl who had happy life with her husband, but her husband - Allen, a handsome boy who wrote poems, but he was found to be a homosexual in their marriage, which gave Blanche a bow, she said harsh words which caused her husband killing himself. It's the deepest shadow in her life that changed Blanche forever. Her inner world was still a 16-year-old pure girl who met her lover, but her desire brought her to strangers. She said: "Yes, I've had many meeting with strangers. After the death of Allan — intimacies with strangers was all I seemed able to fill my empty heart with... I think it was panic, just panic, that drove me from one to another, searching for some protection - here and there, and then - in the most - unlikely places - even, at last." She was an innocent vamp, she chose desire to confront loneliness and death. The last one was desire and despair. Blanche was a typical leftover of Southern belle who had inherited morality from her young age. She was taught what the standards of a respectable woman were and tried to up to them. She longed for respect from men. It can be said that her lies were in her special way to let men respect her. When Blanche passed before the men who were playing poke, she always said: "Please don't get up". When Mitch came to blame her, she said: "So utterly uncavalier! My, my, what a cold shoulder! And such uncouth apparel! Why, you haven’t even shaven! But I forgive you.” In her mind, a man should show respect to a woman. But in such a society and before men brutal like Stanley, it was an ironic dream. When Mitch found her secret, she said: "My youth was gone up the water - spout, and - I met you. You said you needed someone. Well, I needed someone, too. I thanked God for you, because you seemed gentle - a cleft in the rock of the world that I can hide in! But I suppose I was asking, hoping - too much! " In fact, we can see Mitch was not the style that gained favor, she chose him only because he was gentle and kind, but a common man even disliked her, she was completely despaired. Therefore, going insane is Blanche's defend of her dreaming world against the reality. Blanche took the bus named "Desire" to find Elysian fields, but she arrived at her grave. Maybe this meant her desire destroyed her, but she ever said: "Death - I used to sit here and she used to sit over there and death was as close as you are... The opposite is desire. How could you wonder? How could you possibly wonder! ”

\section{Stanley}

Stanley was a Polish who was born in the Unites States. He was common, "common like dirt" in his own word. He liked straight way to express emotion and satisfy his desire, he was one of immigrants who can be called "New American", powerful and simple. As a man, he took on all the responsibility in his family; he was rude, but Stella and he loved each other. Before Blanche appeared, they had a happy life. He disliked Blanche at first, she was completely different from him, and he loved his way so he cannot bear one woman who tried to change his life. When he heard Belle Reve was sold, he wanted to maintain her wife's rights instead of comforting Blanche. When he found Blanche was a cheater, he told Stella and Mitch immediately in spite that Stella loved her sister and Mitch was about to marry Blanch. He did and judged in his own way. So he lacked of enough humanity.

The world in Williams' works was one in the mode of patriarchal culture, where men's masculinity is mainly measured through power. Compared with women, men were endowed with economic superiority, influential powers or family authority. Collectively, men in the 1950s held the vast majority of powering the form of money, social influence, and direction of the world. Stanley, about twenty-eight or thirty years old, because of being the survival of the Second World War, naturally possessed the personality of masculine, power, courage and arbitrariness. As a member of 
working class, he dressed roughly, in blue denim work clothes at his first showing act; he cannot afford pearls, gold bracelets, diamonds, a crown, and rhinestones for his life companion. Stella, however, was still content with the present life. In front of buddies, Stanley was the soul and dominator; for Stella, he was the commander-in-chief; for others, he cannot remove his pugnacious nature. The conflict between Stanley and Blanche was obvious from the beginning to the end. Stanley was surliness while Blanche was preciosity, they are two extremely different of characters, they were too abhorrent to bear each other, while Stanley was so strong and Blanche was delicate, the tragedy happened at last.

\section{Stella}

In A Streetcar Named Desire, Blanche's sister Stella was also a tragic heroine. If we defined Blanche's tragedy as a tragedy of struggle, then Stella's tragedy was a tragedy of tolerance. Stella belonged to the well-breeding class. She came from a decent family, and was elegant in her manners. However, she married a "Polack" - Stanley, whose earliest manhood "has been pleasure with women, the giving and taking of it, not with weak indulgence, dependently, but with the power and pride of a richly feathered male bird among hens". The conventional patriarchal culture confined women at home to behave well as an eligible house wife. Stella, with no job, had to stay at home and acted as Stanley's fine wife, but their wild love made her content with the present living condition even if Stanley was not so successful. Stanley was brutal, rude in manners and words. He abused Stella and Blanche verbally and physically, and paid no respect to them. Facing all these, Stella chose to tolerate. She forgot her "bringing up" and lived with a man of a different social class. In the end of the novel, she chose not to believe Blanche's words that Stanley had raped her. She gave up her beloved sister facing with the cruel reality, Stella did not choose to escape, like Blanche did. She would rather tolerate. She lived in two rooms, but thought, "it's not that bad at all". When Blanche asked her to leave Stanley, she answered: "People have got to tolerate each other's habits". However, she knew what things ought to be. Stella loved her sister and understood her. She was the only person who knew what kind of woman Blanche used to be, but cannot find a way for her. To some extent, Blanche symbolized illusion and imagination, while Stanley, reality. When finally Stella must choose between Blanche, her sister, and Stanley, her husband, she knew there was not a middle way. She chose reality which was cruel, but she was more realistic than Blanche, and knew how to tolerate it. Stella's tragedy was also caused by the society. Women like her were helpless before reality. Confronting with abuses, they had no way to escape. A Streetcar Named Desire was a tragedy, especially a tragedy of women. Abused by the male in the society, a woman had to choose either to struggle or to tolerate. Blanche lived in her world of imagination but was finally thrown into the cruel reality. Stella tried to tolerate, and had to give up her sister and could not find her way out. Confronting with such a society, women were totally helpless.

Blanche's illusion not only gave her peace but also give her fear. The longer she lived in her illusion, the more horrible she felt for the reality. As time began to leave traces on her face, Blanche still pretended to be a young woman for her real youth who was destroyed by reality. She used flowery language to confuse others. But in her inner world, her fear made her feel older than her real age. She cannot found others gaze at her, even her own sister. Blanche find comfort in the dark, which others cannot see her face too clear, which hid the damages of time: "I like the dark, the dark is comforting to me”. That explained why she never appeared in bright and direct light, especially in front of her lover. Another reason for her dislike of light was that light symbolized another reality - her already gone gracious past, including her wonderful first love and her lost dignity, which was in sharp contrast with her present life.

\section{Summary}

Blanche was the victim of patriarchy. She put too much dependence on men, with expectation of saving her destiny by men but fell into a more miserable and pitiful situation. Female was nothing in a man-dominated society where men in their inner thoughts never put their love for women 
before their personal dignity. Besides, the economic dependence and influence by the traditional conventions made women hard to put their dreams about happy life on the basis of self-struggle and unswerving pursue. It was the fundamental reason that led up to the tragic fate of Blanche.

Blanche's tragedy was doomed and inevitable in the male-dominated patriarchal society. The symbols that Williams used in the play such as Blanche's travel from Desire cemeteries then to Elysian Fields, the moth imagery and the appearance of the Mexican woman all indicated Blanche's tragic fate. Blanche fought against her fate and insisted on pursuing her ideals and pure love, and she never surrendered to her tragic fate. Before coming to New Orleans, Blanche had suffered the suicide of her beloved husband, the successive death of her family members and the loss of Belle Reve. All these pains had driven her on the verge of lunacy, that is to say, Blanche's inner world had already begun to shatter and her mental health has already been in a shaky status before she comes to New Orleans. Besides, Blanche was a very complicated person with split character which embodied her inner struggle. The fragility and adamancy of her character contradicted with each other and made Blanche a split object. What is worse, Blanche was tortured by the conflict between desire and reality. Instead of facing the reality bravely, Blanch separated from the desire and reality unreasonably and retreated in the world of fantasy, escaping the harsh reality into illusions. Being caught in the dilemmas and living in illusions, Blanche's self-defects made herself unable to survive in the changing world.

\section{References}

[1] Rubinstein, Annette T.. American Literature Root and Flower [M]. Foreign Language Teaching and Research Press, 1998.

[2] Li Gongzhao, An Introduction to $20^{\text {th }}$ Century American Literature [M]. Xi'An Jiaotong University Press, 2001. 